\title{
EKSPLORASI MIKROORGANISME INDIGENUSINSEPTISOLS
}

\author{
Nurmala Pangaribuan \\ FMIPA Universitas Terbuka \\ e-mail:nurmala@ecampus.ut.ac.id
}

\begin{abstract}
Inseptisols have various types and densities of microorganisms. Plants that are cultivated in Jatinangor inseptisol fields have a root system that contains a large number of microorganisms. This study aims to be able to provide precise information about the potential resources of microorganisms, bacteria, mycorrhizae from the location of planting corn and soybeans on Jatinangor and Ciparanje inseptisols, Sumedang, West Java. This research activity includes (1) soil sampling which was then isolated on oblique agar media observed with a microscope, (2) identification of spore types, identification of CMA using the Manual for The Identification of Mychorhiza Fungi, (3) calculating the number of spores using the Filter Method Wet Pacioni and Centrifugation Technique from Brunndret. The results showed the number of Bradyrhizobium sp., was found in the former soil of soybean cropping in Jatinangor and Ciparanje, which was 7,75 $\times 108 \mathrm{cfu} / \mathrm{g}$, higher than in the former corn crop, 1,80 107 cfu / $g$ in Jatinagor and 1,41 x $107 \mathrm{cfu} / \mathrm{g}$ at Ciparanje. Inseptisols Jatinangor and Ciparanje also produce spores of Glomus sp. 14 spores $/ g$ of soil and 12 spores $/ g$ of soil, in the former maize cropland were higher than in the former soybean cropland, which was 10 spores/g of soil.
\end{abstract}

Keywords: inseptisols, bradyrhizobium sp., rhizobium sp., glomus sp., indigenous, exploration

\begin{abstract}
ABSTRAK
Ekosistem inseptisols memiliki jenis dan kepadatan mikroorganisme yang beragam. Tanaman yang dibudidayakan di lahan inseptisol Jatinangor memiliki sistem perakaran yang mengandung berbagai jenis mikroorganisme dalam jumlah besar. Penelitian ini bertujuan untuk dapat memberikan informasi yang tepat tentang potensi sumberdaya mikroorganisme, bakteri, mikoriza dari lokasi penanaman jagung dan kedelai padalahan inseptisol Jatinangor dan Ciparanje, Sumedang, Jawa Barat. Kegiatan penelitian ini meliputi (1) pengambilan sampel tanah yang kemudian diisolasi pada media agar miring yang diamati dengan mikroskop, (2) identifikasi jenis spora, identifikasi CMA menggunakan Manual for The Identification of Mychorhiza Fungi, (3) penghitungan jumlah spora dengan menggunakan Metode Saring Basah Pacionidan Teknik Sentrifugasi dari Brunndret. Hasil penelitian menunjukkan jumlah bakteri Bradyrhizobium sp. Lebih banyak ditemukan pada tanah bekas pertanaman kedelai di Jatinangor dan Ciparanje, yaitu 7,75 × $10^{8} \mathrm{cfu} / \mathrm{g}$, sementara pada bekas pertanaman jagung, di Jatinangor $1,80 \times 10^{7} \mathrm{cfu} / \mathrm{g}$ dan 1,41 × $10^{7} \mathrm{cfu} / \mathrm{g}$ di Ciparanje. Inseptisols Jatinangor dan Ciparanje mengandung Glomus sp., di Jatinangor dan Ciparanje berturut-turut $14 \mathrm{spora} / \mathrm{g}$ tanah dan $12 \mathrm{spora} / \mathrm{g}$ tanah, lebih tinggi pada tanah bekas pertanaman jagung, dibanding pada tanah bekas pertanaman kedelai, yaitu $10 \mathrm{spora} / \mathrm{g}$ tanah.
\end{abstract}

Kata kunci: inseptisols, bradyrhizobium sp., rhizobium sp., glomus sp.,indigenous, eksplorasi 
Inseptisols merupakan salah satu ordo tanah yang penyebarannya cukup luas di Indonesia, maka pengembangan inseptisols untuk pertanian memiliki nilai yang cukup prospektif, termasuk untuk tanaman pangan. Penyebaran inseptisols di Jawa Barat sekitar 2.119 juta ha (Saribun,2008). Inseptisols merupakan tanah muda yang mulai berkembang, pembentukan horizonnya lambat akibat alterasi bahan induk dan memiliki tingkat kesuburan dari sangat rendah sampai tinggi. Inseptisols di Jatinango rmemiliki tingkat kesuburan yang tergolong rendah. Hal ini ditunjukkan oleh $\mathrm{pH}$ tanah yang agak masam, $\mathrm{N}$ - total sedang, Prendah, dan $\mathrm{K}_{2} \mathrm{O}$ rendah. Pada tanah dengan $\mathrm{pH}$ masam, kandungan Mn cukup tinggi dalam tanah.

Pemanfaatan lahan inseptisols yang cukup luas ini untuk pertanian terkendala oleh berbagai masalah yang salah satunya yaitu unsur hara yang rendah. Petani mengatasi masalah tersebut dengan menggunakan pupuk. Kebanyakan petani menggunakan pupuk kimia, namun pupuk kimia ini sangat berbahaya bagi lingkungan. Oleh karena itu, pemanfaatan pupuk hayati atau biofertilizer menjadi salah satu alternatif yang layak dipertimbangkan, karena biofertilizer bersifat ramah lingkungan dan daya persistensi cukup lama di dalam tanah. Istilah biofertilizer digunakan sebagainama kolektif untuk semua kelompok fungsional mikroba tanah yang berfungsi sebagai penyedia hara tanah sehingga menjadi bentuk yang tersedia bagi tanaman (Nugraha, Ardyti, dan Suharjono, 2014).

Pemanfaatan mikroorganisme indigenus diharapkan dapat meningkatkan kesuburan tanah untuk memenuhi persyaratan sebagai lahan pertanian,tetapi tidak merusak ekosistem tanah. Pemanfaatan mikro organisme sebagai biofertilizer merupakan masukan teknologi mikrobia yang mungkin dapat dikembangkan untuk mengatasi masalah pada tanah yang sub optimal, untuk memenuhi persyaratan sebagai lahan pertanian,tetapi tidak merusak ekosistem tanah. Penerapan teknologi perlu dilakukan dengan pendekatan secara holistik dan partisipatif agar sumberdaya lahan terjaga kesinambungan dan kelestariannya.

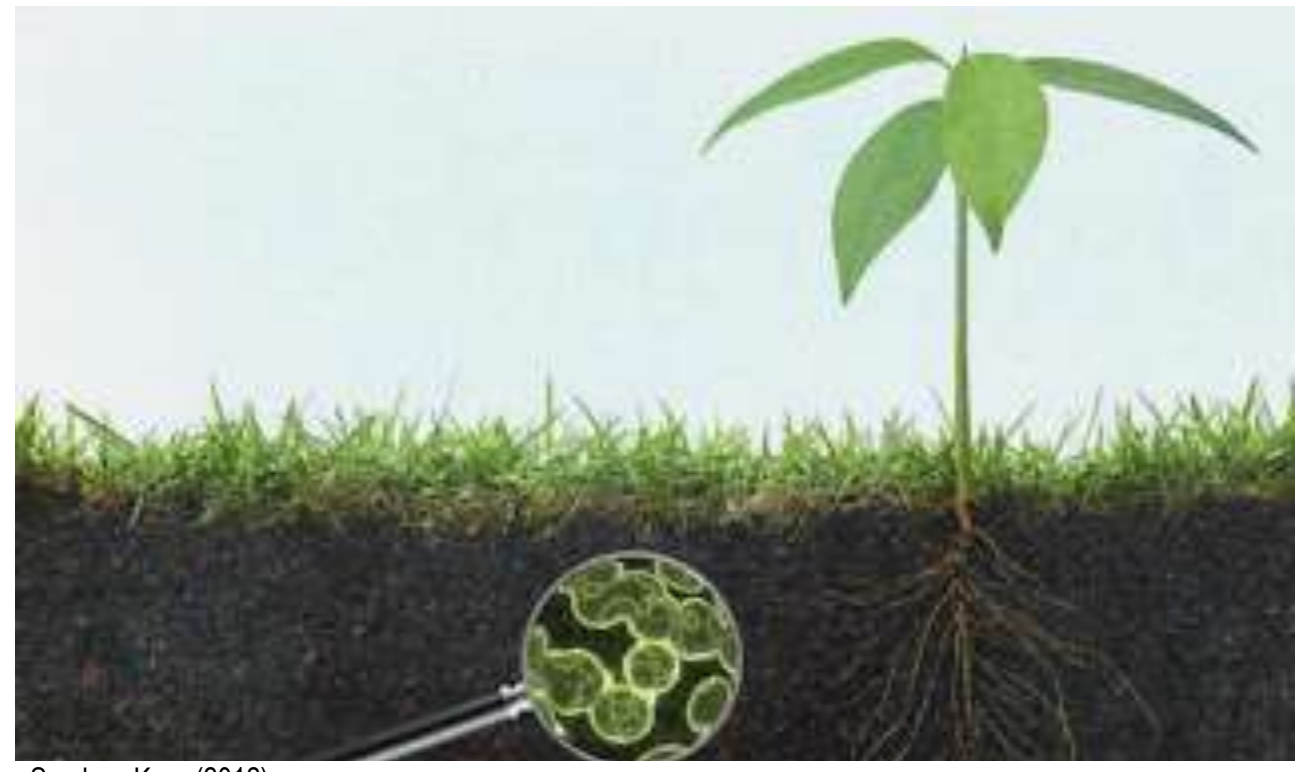

Sumber: Kaur (2012)

Gambar 1. Penampang tanah yang mengandung mikroorganisme tanah 
Mikroorganisme tanah, bakteri dan cendawan mikoriza yang hidup dalam tanah dapat berasosiasi dengan akar tanaman (Brundrett et al., 1996, Simarmata, 2013, dan Pangaribuan, 2014). Mikroorganisme berperan dalam peningkatan penyerapan unsur-unsur hara tanah yang dibutuhkan oleh tanaman seperti P, N, K, Zn, Mg, Cu, dan Ca. Mikroorganisme misalnya bakteri, menjadi salah satu alternatif untuk mengatasi kekurangan unsur hara terutama ketersediaan $\mathrm{N}$ dan $\mathrm{P}$ dalam tanah.

Mikroba sebagai biofertilizer dapat ditemui pada tanah organik maupun pada tanah mineral. Penelitian pada tanah Gambut Rasau, Kalimantan Barat, di lahan budidaya jagung dan kedelai yang belum diinokulasi mengandung 227,67 spora Glomus sp. per $100 \mathrm{gr}$ tanah (Pangaribuan, 2014) dan Bradyrhizobium. Di Pontianak Utara (Sagiman dan Anas, 2005), menemukan mikroorganisme potensial bagi tanaman darigenus Glomus sp., yaitu 1.149,74 propagulinfektif dan 171,8 spora yang dapat membantu penyerapan hara melalui dekomposisi berbagai bahan organik dan pada bagian lain di lahan mineral (Nugraha, Ardyti, dan Suharjono, 2014). Tanah organik banyak mengandung mikroorganisme tanah yang diperlukan tanaman. Bagaimana dengan tanah Inseptisol? Inseptisols merupakan jenis tanah muda yang juga termasuk ke dalam jenis tanah mineral. Kandungan bahan organik kurang dari $20 \%$, atau memiliki lapisan bahan organik yang ketebalannya kurang dari $30 \mathrm{~cm}$ sehingga membuat tekstur tanahnya menjadi ringan.

Penelitian ini bertujuan untuk eksplorasi, menyeleksi isolate mikroba inseptisols, dan mengetahui koleksi bakteri indigenus asal inseptisols Jatinangor, Jawa Barat. Hasil penelitian ini diharapkan dapat memberikan informasi tentang potensi isolat-isolat indigenus asal tanah inseptisol.

\section{METODE}

Percobaan dilakukan di laboratorium Mikrobiologi Fakultas Pertanian UNPAD Jatinangor, Jawa Barat, terletak pada ketinggian $\pm 700 \mathrm{~m}$ di atas permukaan laut, suhu berkisar antara $25-27^{\circ} \mathrm{C}$, tipe curah hujan termasuk tipe $C$ menurut Klasifikasi Schmidt dan Fergusson (1951), berkisar antara110-200 mm bulan ${ }^{-1}$, tipe Agroklimat $\mathrm{C}_{2}$ menurut Oldeman (1975). Sampel tanah diambil dari Jatinangor dan Ciparanje, yang merupakan bekas pertanaman kedelaidan jagung (Pangaribuan, 2016). Tanah inseptisol diambil secara komposit pada lapisan atas $0-20 \mathrm{~cm}$, kemudian dilakukan analisis tanah dan menggunakan metode pada Tabel 1.

Tabel 1. Parameter Analisis Tanah Inseptisol

\begin{tabular}{|c|c|c|}
\hline Parameter & Satuan & Metode Analisa \\
\hline $\mathrm{pH}$ & & $\mathrm{H}_{2} \mathrm{O}$ \\
\hline KTK & $\mathrm{cmol}(+) \mathrm{kg}^{-1}$ & Ekstraksi $\mathrm{NH}_{4} \mathrm{OAC} 1 \mathrm{~N} \mathrm{pH:7}$ \\
\hline C-org & $\%$ & Walkley \& Back \\
\hline $\mathrm{N}$-total & $\%$ & Kjeldhal \\
\hline P2O5 & & Bray I \\
\hline & $\mathrm{cmol}(+) \mathrm{kg}^{-1}$ & Ekstraksi $\mathrm{NH}_{4} \mathrm{OAC} 1 \mathrm{~N} \mathrm{pH:7}$ \\
\hline $\mathrm{Na}$ & $\mathrm{cmol}(+) \mathrm{kg}-1$ & Ekstraksi $\mathrm{NH}_{4} \mathrm{OAC} 1 \mathrm{~N} \mathrm{pH:7}$ \\
\hline $\mathrm{Ca}$ & $\mathrm{cmol}(+) \mathrm{kg}_{1}^{-1}$ & Ekstraksi $\mathrm{NH}_{4} \mathrm{OAC} 1 \mathrm{~N} \mathrm{pH:7}$ \\
\hline $\mathrm{Mg}$ & $\mathrm{cmol}(+) \mathrm{kg}^{-1}$ & Ekstraksi $\mathrm{NH}_{4} \mathrm{OAC} 1 \mathrm{~N} \mathrm{pH:7}$ \\
\hline $\mathrm{KB}$ & $\%$ & \\
\hline $\mathrm{H}$-dd & $\mathrm{cmol}(+) \mathrm{kg}^{-1}$ & Eks. $\mathrm{KCl} 1 \mathrm{~N}$ \\
\hline Al-dd & $\mathrm{cmol}(+) \mathrm{kg}^{-1}$ & Eks. $\mathrm{KCl} 1 \mathrm{~N}$ \\
\hline
\end{tabular}

Sumber: Laboratorium KesuburanTanah dan Nutrisi Tanaman FPUNPAD Jatinangor (2017) 
Metode untuk isolasi bakteri, menggunakan Metode Somasegaran dan Hoben (1994), tertera pada Tabel 2, yaitu menggunakan NaOCII 1\%, media Yeast Mannitol Agar (YEMA), pewarna Congo Red (CR), Brom Thimol Blue (BTB), dan Nutrisi Fahroush Cand N-free. Isolat bakteri ditumbuhkan pada media dasar Yeast Manitol Agar (YEMA) ditambah beberapa jenis pewarna indikator seperti Congo Red (CR) dan Brom Thymol Blue (BTB). Kemudian diinkubasi pada suhu $27^{\circ} \mathrm{C}$ sampai dengan $28^{\circ} \mathrm{C}$, selama 3 hingga 5 hari dalam kondisi gelap. Pengamatan koloni dilakukan setiap hari, diamati pertumbuhan dan dihitung jumlah koloninya. Perlakuan diulang10 kali.

Tabel 2. Media Yeast Mannitol Agar (YEMA)

\begin{tabular}{ll}
\hline Bahan & Dosis \\
\hline$\left(\mathrm{gl}^{-}\right)$Sari kamir & 0,5 \\
Mannitol & 10.000 \\
$\mathrm{~K}_{2} \mathrm{HPO}_{4}$ (Dipotassium phosphate) & 0,5 \\
$\mathrm{MgSO}_{4} \cdot 7 \mathrm{H}_{2} \mathrm{O}$ (Magnesium sulphate) & 0,2 \\
$\mathrm{NaCl}$ (Sodium chloride) & 0,1 \\
Agar Bakto & 15.000 \\
Congo red/bromtimol blue & $10 \mathrm{ml}(0.25 \%)$ dalam akuades $1.000 \mathrm{ml}$ \\
pH & $25^{\circ} \mathrm{C}, 6,8 \pm 0,2$ \\
Sumber: Balai Besar Penelitian dan Pengembangan Sumber Daya Lahan Pertanian, Badan Penelitian dan \\
\multicolumn{2}{l}{ Pengembangan Pertanian, Departemen Pertanian (2007). }
\end{tabular}

Penghitungan jumlah koloni menggunakan Metode Cawan Hitung (platecount). Isolat yang diperoleh dipindahkan ke dalam medium agar miring, kemudian dimurnikan. Koloni yang tumbuh tunggal ditanam dalam media miring sebagai kultur murni. Bahan dan dosis tertera pada Tabel 3.

Tabel 3. Larutan Bebas C dan N Nutrisi untuk Identifikasi Bradhyrhizobium sp.

\begin{tabular}{ll}
\hline Bahan & Dosis \\
\hline (g) $\mathrm{CaCl}_{2}$ & 0,1 \\
$\mathrm{MgSO}_{4} \cdot 7 \mathrm{H}_{2} \mathrm{O}$ & 0,12 \\
$\mathrm{KH}_{2} \mathrm{PO}_{4}$ & 0,1 \\
$\mathrm{Na}_{2} \mathrm{HPO}_{4} \cdot 2 \mathrm{H}_{2} \mathrm{O}$ & 0,15 \\
Ferric Citrate & 0,005 \\
$\mathrm{Mn}, \mathrm{Cu}, \mathrm{Zn}, \mathrm{B}, \mathrm{Mo}$ & traces (sedikit saja) Aquadesh (air destilasi) $1.000 \mathrm{ml}$ \\
& Sterilisasi pada suhu $121{ }^{\circ} \mathrm{C}$ selama 20-30 menit. \\
\hline
\end{tabular}

Sumber: Somasegaran dan Hoben (1994)

Isolasi terhadap mikoriza indigenusinseptisols, jenis mikoriza Glomus sp, menggunakan Metode Penyaringan Basah dan Teknik Sentrifugasi (Pacioni,1992, dan Brundrett, et al.,1996) meliputi: Glukosa 60 \%, Poli Vinilalcohol Lacto Gliserol (PVLG) dan pereaksi Melzer untuk penguat spora,dan air destilasi, kantong plastik, cool box, spidol permanen, saringan bertingkat berbagai ukuran $(125 \mu, 250 \mu, 500 \mu)$, sentrifus, cawanpetri, beker glass, mikroskop binocular untuk melihat spora yang dilengkapi kamera, pinsetspora, jarumose, standar colourchart. Identifikasi spora menggunakan Standar Colour Chart (Brundrett,et al.,1996). 
Isolasi diawali dengan mencampurkan tanah sampel $100 \mathrm{gr}$ dengan $1.000 \mathrm{ml}$ air dan diaduk merata, disaring dalam satu set saringan dengan ukuran $500 \mu \mathrm{m}, 250 \mu \mathrm{m}, 125 \mu \mathrm{m}$ secara berurutan dari atas ke bawah (bertingkat). Dari saringan bagian atas disemprot dengan air kran, kemudian saringan paling atas dilepas dan saringan kedua kembali disemprot dengan air kran. Tanah yang tersisa pada saringan $125 \mu \mathrm{m}$ dipindahkan ke dalam tabung, kemudian ditambahkan aquades sebanyak $25 \mathrm{ml}$ dan disentrifuse dengan kecepatan $2.000 \mathrm{rpm}$ selama 5 menit. Hasil sentifuse dibuang supernatannya, dan ditambahkan glukosa $60 \%$. Tabung sentifuse ditutup rapat dan disentrifugasi kembali dengan kecepatan 2.000 rpm selama 1 menit. Selanjutnya larutan supernatant tersebut (yang mengandung spora) dituang ke dalam cawan petri dan diamati di bawah mikroskop, dan dilakukan10 kali ulangan.

Identifikasispora, yang diamati adalah karakter morfologi, meliputi: bentuk spora, ukuran spora, warna spora, susunan spora,dan bentuk hifa spora Glomus sp. Hasil ekstraksi, kemudian diletakkan dalam larutan Melzer dan PVLG pada satu kaca preparat. PVLG dan Melzer merupakan senyawa penguat spora, berdasarkan Standar Colour Chart. Selanjutnya spora-spora tersebut dipecahkan secara hati-hati dengan cara menekan kaca penutup preparat (Badan Penelitian dan Pengembangan Pertanian Kementrian Pertanian: Metode Analisis Biologi Tanah, 2012).

Perkembangan spora Glomus sp., dari ujung hifa membesar sampai mencapai ukuran maksimal dan terbentuk spora. Hifa yang berkembang dan membentuk spora disebut chlamydospora,sering terlihat jelas sisa dinding hifa pada permukaan spora. Isolat yang diamati adalah spora yang sehat,ditandai dengan bentuk spora bulat tidak gepeng atau pecah.

\section{HASIL DAN PEMBAHASAN}

Pada dua lokasi sampel tanah asal Jatinangor dan Ciparanje mengandung bakteri Bradyrhizobium sp. Dan Rhizobium sp., serta mikoriza jenis Glomussp. Isolasi bakteri indigenus pada inseptisols ditemukan jenis bakteri Bradyrhizobium sp yang dicirikan pertumbuhan lambat 5 sampai 7 hari, dan memiliki reaksi basa. Sagiman (2005) dan Kaur et al. (2012), juga melaporkan bahwa hasil isolasi dari rhizosfer kedelai ditemukan bakteri Bradyrhizobium japonicum yang dicirikan pada media YEMA (BTB) berwarna biru, pertumbuhan isolat lambat,tahan pada kondisi masam, yang menjadi ciri khas keberadaan bakteri ini. Rhizobium yang dicirikan pada media YEMA (BTB) berwarna merah, pertumbuhan isolat agak cepat 3-5 hari, tahan pada kondisi masam-basa. Penelitian pada tanah organik dilaporkan, trapping bakteri bintil akar diperoleh 60 galur Bradyrhizobium japonicum yang dicirikan pertumbuhan lambat 5 sampai 7 hari, dan memiliki reaksi basa.

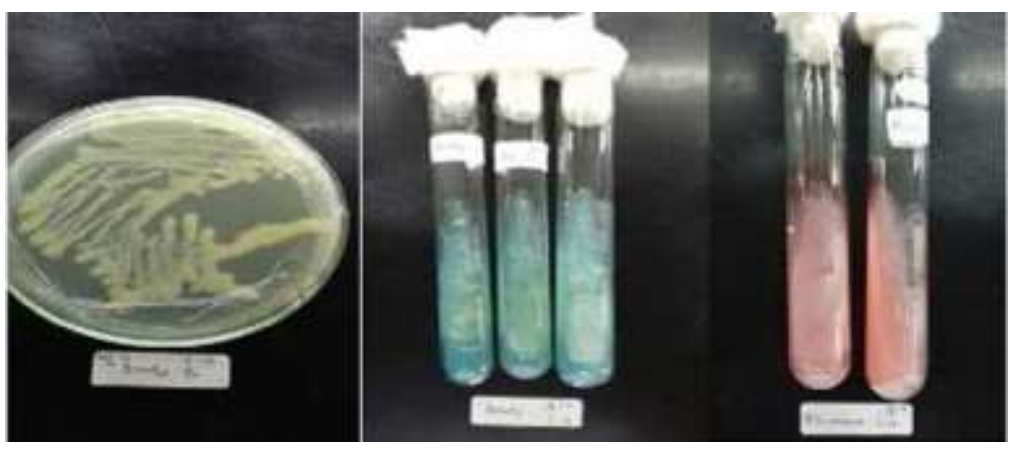

Gambar 2. Hasil isolasi bakteri Bradyrhizobium sp. dan Rhizobium sp. pada inseptisols 
Analisis laboratorium hasil isolasi bakteri Inseptisols Ciparanje dan Jatinangor disajikan pada Tabel 4 dan Tabel 5.

Tabel 4. Isolasi Bakteri Inseptisols Ciparanje

\begin{tabular}{clllcl}
\hline KodeLab & Kode Sample & Parameter & Metode & Hasil Analisis & Satuan \\
\hline S-16 & Jagung & Total Bakteri & Total Plate Count & $7,90 \times 10^{8}$ & $\mathrm{cfu} / \mathrm{g}$ \\
S-16 & Jagung & Bradyrhizobium sp. & Total Plate Count & $1,41 \times 10^{7}$ & $\mathrm{cfu} / \mathrm{g}$ \\
S-16 & Jagung & Rhizobium sp. & Total Plate Count & $8,00 \times 10^{7}$ & $\mathrm{cfu} / \mathrm{g}$ \\
S-17 & Kedelai & Total Bakteri & Total Plate Count & $7,75 \times 10^{9}$ & $\mathrm{cfu} / \mathrm{g}$ \\
S-17 & Kedelai & Bradyrhizobium sp. & Total Plate Count & $7,75 \times 10^{8}$ & $\mathrm{cfu} / \mathrm{g}$ \\
S-17 & Kedelai & Rhizobium sp. & Total Plate Count & $5,25 \times 10^{7}$ & $\mathrm{cfu} / \mathrm{g}$ \\
\hline Tabel 5. Isolasi Bakteri Inseptisols Jatinangor & & & \\
\hline Kode Lab & Kode Sample & Parameter & Metode & Hasil Analisis & Satuan \\
\hline S-18 & Jagung & Total Bakteri & Total Plate Count & $7,50 \times 10^{8}$ & cfu/g \\
S-18 & Jagung & Bradyrhizobium sp. & Total Plate Count & $1,80 \times 10^{7}$ & cfu/g \\
S-18 & Jagung & Rhizobium sp. & Total Plate Count & $7,50 \times 10^{7}$ & cfu/g \\
S-19 & Kedelai & Total Bakteri & Total Plate Count & $7,30 \times 10^{9}$ & cfu/g \\
S-19 & Kedelai & Bradyrhizobium sp. & Total Plate Count & $7,75 \times 10^{8}$ & cfu/g \\
S-17 & Kedelai & Rhizobium sp. & Total Plate Count & $5,50 \times 10^{7}$ & cfu/g \\
\hline
\end{tabular}

Hasil isolasi bakteri asal tanah inseptisol Ciparanje dan Jatinangor padaTabel 4 dan Tabel 5 , menunjukkan jumlah bakteri Bradyrhizobium sp lebih banyak ditemukanp ada tanah bekas pertanaman kedelai, dibandingkan dengan bekas pertanaman jagung. Hal ini ada hubungannya dengan kemampuan mikroorganisme bakteri Bradyrhizobium sp., Rhizobiumsp., yang mampu bersimbiosis/bersinergi dengan akar tanaman kedelai untuk memfiksasi/menambat $\mathrm{N}$ dari udara secara hayati melalui proses inokulasi membentuk bintil akar. Jadi mikroorgnisme ini berperan dalam meningkatkan ketersediaan nitrogen bagi tanaman kedelai.

Bradyrhizobiumsp.,dicirikan sebagai bakteri bintil akar yang mempunyai pertumbuhan lambat dan mampu menghasilkan basa pada medium ekstrak khamirmanitolagar (SKM=YEMA).Tanaman inang utama bakteri Rhizobium sp adalah legumesubtropis sedangkan genus Bradyrhizobium adalah legumtropis (Simarmata, 2013).

Produktivitas tanah dapat ditingkatkan dengan menguraikan bahan organik secara mikrobiologis. Bakteri sangat melimpah (too numerous to count) pada tanah yang pembentukannya sudah mendekati sempurna,pada kedalaman 0-10 cm jumlah bakteri lebih tinggi dibanding pada kedalaman 100-110 cm, karena kandungan bahan organik pada permukaan tanah lebih tinggi dan 
merupakan sumber makanan bakteri. Bakteri yang akan diisolasi dapat berupa biakan murni atau populasi tercampur. Bila biakan yang akan diidentifikasi ini tercampur, perlu dilakukan pemurnian lebih dahulu. Setelah diperoleh biakan murni dapat dilakukan serangkaian uji untuk memperoleh cirri morfologi dan biokimia dari isolat. Identifikasi bakteri didasarkan pada morfologi, sifat biakan, dan sifat biokimiawi (Armiadi,2009).

Menurut Permentan No.70/291/2011, hal 47-52, nilai uji mutu pupuk organik dalam pupuk hayati, standar mutu sel hidup bakteri Bradyrhizobium sp. Dan Rhizobium sp. Adalah $\geq 107 \mathrm{cfu} / \mathrm{g}$ berat kering contoh (Peraturan Menteri Pertanian No.70/291/2011). Hasil penelitian ini menunjukkan bahwa total bakteri indigenus Jatinangor dan Ciparanje lebih tinggi pada lahan bekas kedelai dibanding lahan bekas jagung (Tabel 4 dan Tabel 5).

Hasil penelitian untuk Inseptisols Jatinangor pada tanah bekas pertanamankedelai terdapat jumlah Bradyrhizobium sp. 7,75 × $10^{8} \mathrm{cfu} / \mathrm{g}$, dan jumlah Rhizobium sp. 5,50 × $10^{7} \mathrm{cfu} / \mathrm{g}$ (Tabel 5), dan di Ciparanje Bradyrhizobium sp.7,75 × $10^{8} \mathrm{cfu} / \mathrm{g}$, Rhizobium sp. 5,25 × $10^{7} \mathrm{cfu} / \mathrm{g}$ (Tabel 4). Hasil penelitian Pangaribuan (2017), menunjukkan bahwa populasi kedua jenis bakteri tersebut cukup besar, diduga mikroorganisme tanah ini masih tertinggal di lahan, dan populasi tersebut masih mampu menodulasi akar tanaman leguminosa, walau tanpa/tidak dilakukan inokulasi. Bakteri Bradyrhizobium sp.dan Rhizobium sp. mampu hidup pada tanah masam, pada $\mathrm{pH}$ berkisar 4,6 (Sagiman, 2005, Pangaribuan, 2014 \& Handayani, 2009).

Tabel 6. Isolasi Mikroorganisme Indigenus Inseptisols Jatinangor dan Ciparanje Jatinangor

\begin{tabular}{rlllcl}
\multicolumn{1}{r}{ Jatinangor } & & & & \\
\hline Kode Lab & Kode Sampel & Parameter & Metode & $\begin{array}{c}\text { Hasil } \\
\text { Analisis }\end{array}$ & Satuan \\
& & & & 10 & Spora/g \\
S-20 & Kedelai & Populasi Glomus sp. & Penjaringan Basah & 14 & Spora/g \\
\hline Jagung & Populasi Glomus sp. & Penjaringan Basah & & \\
Ciparanje & & & & Hasil & Satuan \\
\hline Kode Lab & KodeSampel & Parameter & Metode & Analisis & \\
\hline S-20 & Kedelai & Populasi Glomus sp. & Penjarinngan & 10 & Spora/g \\
S-20 & Jagung & Populasi Glomus sp. & Penjaringan Basah & 12 & Spora/g \\
\hline
\end{tabular}

Hasil penjaringan Glomus sp., di lokasi pengambilan sampel tanah Jatinangor dan Ciparanje menunjukkan jumlah yang relatif sama. Hasil penelitian menunjukkan bahwa jumlah Glomus sp. Lebih banyak ditemukan pada tanah bekas pertanaman jagung dibanding pada lahan bekas pertanaman kedelai (Tabel 6). Sebagai contoh di Jatinangor jumlah spora Glomus sp pada jagung mencapai 14 spora/g tanah dan pada kedelai 10 spora/g tanah. Hal ini berhubungan dengan akar serabut tanaman jagung merupakan inang yang cocok bagi Glomus sp. Akar tanaman yang terinfeksi Glomus sp. mempunyai eksudat akar yang berbeda dengan eksudat akar yang tidak terinfeksi. Hifa dan seludang cendawan akan membungkus permukaan akar, volume akar lebih besar, sehingga daya jelajah akar dan kemampuan menyerap unsur hara lebih besar. 
Hasil penelitian ini menunjukkan bahwa inseptisol Jatinangor dan Ciparanje berpotensi untuk dikembangkan sebagai media tanam. Kandungan mikroorganiame tanah cukup tinggi (Peraturan Menteri Pertanian No. 70/291/2011). Mengelola lahan dengan mempertahankan pH 4, 5-4,7 sudah menjamin mikroorganisme potensial dapat hidup dengan baik.

Penelitian Handayani (2009), melaporkan bahwa tanah organik kayaakan mikroorganisme indigenous seperti bakteri Rhizobium sp, Bradyrhizobiumjaponicum, Glomus sp, yang dapat beradaptasi dengan kondisi pH rendah, ketersediaan Nrendah (C/Nlebar). Pada kondisi seperti ini mikroorganisme yang memiliki reaksi basa mampu beradaptasi. Simarmata (2013), melaporkan bahwa Bradyrhizobium japonicum dapat bertahan hidup di tanah masam, dengan $\mathrm{pH}$ 4,5. Pangaribuan (2016), pada tanah mineral Inseptisol Jatinangor dan Ciparanje, bakteri Bradyrhizobium sp., Rhizobium sp., indigenus, dan Glomus sp., ditemukan pada bekas pertanaman kedelai dan jagung. Bakteri dan Mikorizaindigenus dapat memfiksasi $\mathrm{N}$ dan melarutkan fosfat dan tersedia bagi tanaman. Hal ini memberi harapan baru untuk mengelola inseptisols, tanah mineral, pH rendahmasam, untuk pembudidayaan tanaman kedelai dan jagung. Penggunaan mikroorganisme tanah berpotensi sebagai agen biofertilizer (pupuk hayati), dan menekan/mengurangi penggunaan pupuk anorganik (Nurbaity, Herdiyantoro, dan Mulyani, 2011).

\section{SIMPULAN}

Inseptisols Jatinangor dan Ciparanje mengandung bakteri indigenus jenis Bradyrhizobium sp. dan Rhizobium sp. Di Jatinangor dan Ciparanje jumlah bakteri Bradyrhizobiumsp., pada tanah bekas pertanaman kedelai masing-masing jumlahnya $7,75 \times 10^{8} \mathrm{cfu} / \mathrm{g}$, lebih tinggi dibanding pada tanah bekas pertanaman jagung, yaitu 1,80 x 107 cfu/g Jatinangor, $1,41 \times 10^{7} \mathrm{cfu} / \mathrm{g}$ di Ciparanje. Sebaliknya jumlah Glomus sp., lebih tinggi dijumpai pada lahan bekas pertanaman jagung. Jumlah spora Glomus sp., pada lahan bekas pertanaman jagung di Jatinangor mencapai 14 spora/g tanah, dan di Ciparanje 12 spora/g tanah, sedangkan di lahan bekas kedelai di Jatinangor dan Ciparanje 10 spora/g tanah.

Eksplorasi mikroorganisme indigenus pada tanah Inseptisol diharapkan dapat berkontribusi langsung dalam memberikan solusi dan menyelesaikan berbagai permasalahan di Indonesia yang terkait dengan pemanfaatan mikroba, baik dari aspek pangan, energi, pertanian, lingkungan, maupun industri. Sebagai contoh aplikasi mikroba untuk proses reklamasi lahan yang rusak akibat aktivitas pertambangan dan proses instalasi pengolahan limbah pabrik.

Di samping itu hasil penelitian dapat sebagai sumber basis data yang diperlukan oleh akademisi di Indonesia dalam mengakses sumber informasi mengenai aspek biodiversitas mikroba berikut potensinya pada tanah mineral inseptisol.

\section{REFERENSI}

Agen Biofertilizer. (2017). Laporan Penelitian Bidang IImu. LPPM-UT.2017.

Armiadi. (2009). Penambatan nitrogen secara biologis oleh tanaman leguminosa. Wartazoa, 19 (1): 23-30. Balai Penelitian Ternak Bogor.

Balai Besar Penelitian dan Pengembangan Sumber Daya Lahan Pertanian Badan Penelitian dan Pengembangan Pertanian Departemen Pertanian. Buku Seri. (2007). Balai Besar Penelitian dan Pengembangan Sumber Daya Lahan Pertanian. Bogor. Jawa Barat.

Biologi Tanah. (2012). Peraturan Menteri Pertanian Nomor 70/291/2011, hal47-52. Jakarta, 25 Oktober 2011. 
Brundrett, M. C, Bougher, N., Dells,B., Grove, T., \& Malajozuk, N. (1996). Working with mycorrhizasinforestry and agriculture. Australian Centrefor International Agricultural Research: Canberra.New Phytologist. Vol. 135, Issue 4, p 783-788.

Handayani, L. (2009). Inokulan Bradyrhizobium toleran Asam-Al Uji Viabilitas dan Efektivitas Simbiotik terhadap Tanaman Kedelai. Tesis. Sekolah PascaSarjanalPB Bogor.

Kaur, H., P. Sharma, N. Kaur, \& B.S., Gill. (2012). Phenotypic and Biochemica Characterization of Bradyrhizobium and Ensifer spp. Isolated from Soybean Rhizosphere. Department of Microbiology Department of Plant Breeding and Genetics Punjab Agricultural University, Ludhiana. Bioscience Discovery, 3(1):40-46.

Nugraha, R.,Ardyati, \& T.Suharjono, S. (2014). Eksplorasi Bakteri Selulolitik yang Berpotensi Sebagai Agen Biofertilizer dari Tanah Perkebunan Apel Kota Batu,Jawa Timur.Jurnal Biotropika, 2 (3): 159-163.

Nurbaity,A., D. Herdiyantoro, \& O. Mulyani. (2011). The use of organic matter as acarrier of inoculant of Arbuscular Micorrhizal Fungi. Jurnal Biologi, XIII(1):17-11.

Oldeman, L.R. (1975). Agroclimatic map of Java \& Madura. Contr. of Centra Res. Inst. for Food Crops 16/76. Bogor.

Pacioni,G. (1992). Wet sieving and decanting techniques for the extraction of spores of $\mathrm{V}$ Amycorrhyzal fungi, di dalam:Methods in Microbiology. Academic Press Inc. San Diego 24: p. 317-322.

Pangaribuan, N. (2014). Trapping Of Indigenous Arbuscular Mycoriza Fungi Fromphysic Corn And Nuts At Peatland West Kalimantan.Jurnal Agro,1 (1): 50-62.

Pangaribuan, N. (2016). Abu Cangkang Uji Penggunaan Sawit (ACs) Sebagai Sumber Hara pada Inceptisols: Tanaman Indikator Kacang Kedelai (Glicine MaxL. Merr). Laporan Penelitian LPPM-UT. 2016.

Pangaribuan, N. (2017). Eksplorasi Mikroorganisme Indigenus Inceptisols Jatinangor Sebagai

Sagiman,S. \& I. Anas. (2005). Increasing soybeanyieldonpeatsoils throughino culation of selective Bradyrhizobium japonicum. SeminaronThe9th National Congress of Indonesian Society for Microbiology, 25-26 th August 2005, Sanur Paradise Plaza Hotel, Bali.

Saribun, D. (2008). Pengaruh Pupuk Majemuk N,P, K pada Berbagai Dosis terhadap pH, PPotensial dan P-Tersedia serta Hasil Caysin (Brassicajuncea) pada Fluventic Eutrudepts Jatinangor. Laporan Penelitian Pengujian Pupuk. Bandung: Jurusan IImu Tanah Fakultas Pertanian Universitas Padjadjaran.

Simarmata,T. (2013). Peranan Pelarut P dan K, CMA dan PGPR dalam Meningkatkan Ketersediaan Hara dan Pertumbuhan Tanaman. Bandung: Laboratorium Biologi dan Mikrobiologi Tanah. Fakultas Pertanian, Universitas Padjajaran.

Somasegaran,P., \& H.J.Hoben. (1994). Handbook for Rhizobia Methods in Legume- Rhizobium Technology. New York: Springer-Verlag. 